\title{
Rifampicin for lepromatous leprosy: nine years' experience
}

\author{
M F R WATERS, R J W REES, J M H PEARSON, A B G LAING, H S HELMY, R H GELBER
}

British Medical fournal, 1978, 1, 133-136

\section{Summary and conclusions}

Over 100 patients with lepromatous leprosy were treated with rifampicin in a series of pilot, uncontrolled, and controlled trials in 1968-77. The rapid bactericidal effect of rifampicin on Mycobacterium leprae was confirmed. Clinical improvement became apparent sometimes as early as 14 days after the start of treatment. Nevertheless, a few persisting viable $M$ leprae were detected as long as five years after the start of treatment with rifampicin either by itself or in combination with the bacteriostatic drug thiambutosine. Treatment with rifampicin and dapsone for six months reduced the number of persisting leprosy bacteria more than treatment with dapsone alone.

Although rifampicin proved more effective than dapsone, it is unlikely that used by itself it can significantly shorten the length of treatment in lepromatous leprosy. Therefore initial intensive combined treatment with two or more bactericidal drugs (including rifampicin) warrants further investigation in both untreated leprosy and lepromatous leprosy resistant to dapsone.

\section{Introduction}

Rifampicin was first used for treating leprosy after it was found to inhibit the multiplication of Mycobacterium leprae in mice and

\footnotetext{
Leprosy Research Unit, National Leprosy Control Centre, Sungei Buloh, Selangor, Malaysia

M F R WATERS, FRCP, MRCPATH, director

J M H PEARSON, DM, MRCP, research physician (now director, Medical Research Council Leprosy Project, PO Box 1005, Addis Ababa, Ethiopia) A B G LAING, MD, DTM\&H, research physician

H S HELMY, MB, BS, medical officer (now Director of Rural Health Services, Shebin el Koom, Menoufia, Egypt)

R H GELBER, MD, Hooper Foundation research fellow (now chief, Infectious Disease Service, United States Public Health Services Hospital, San Francisco, California 94118)

Laboratory for Leprosy and Mycobacterial Research, National Institute for Medical Research, London NW7 1AA

R J W REES, MB, FRCPATH, head of laboratory
}

after our pilot clinical studies had indicated that it was initially more effective than standard dapsone treatment. We also found that rifampicin was unique among anti-leprosy drugs in possessing rapid bactericidal activity. ${ }^{1}$ These observations, substantiated by others, ${ }^{2-4}$ encouraged further investigations. From 1968 to 1977 over 100 patients with lepromatous leprosy have been treated with rifampicin at the Leprosy Research Unit, Malaysia. We report here the results of a series of wide-ranging short- and long-term clinical trials, including bacteriological surveillance by mouse footpad inoculation.

\section{Patients and methods}

\section{BACTERIOLOGICAL STUDIES}

Because $M$ leprae cannot be cultured in vitro, bacterial growth was assessed in the footpads of strain CBA mice. The tests were performed at the National Institute for Medical Research, London. Both hind footpads of normal mice were inoculated with $10^{4}$ acid-fast bacilli (AFB), and scored positive if $5 \times 10^{4}$ or more bacilli were recovered by 12 months. ${ }^{5}$ Six mice were used for each test. In many assessments similar groups of immunologically deficient CBA mice ( $T / R$ mice, who had undergone thymectomy in adolescence and subsequent irradiation by five exposures of 200 rads every two weeks) were also included. Unlike normal mice, the $T / R$ mice supported growth from inocula $>10^{4} \mathrm{AFB} /$ footpad and they also had a possible overall increased susceptibility to $M$ leprae. ${ }^{6}$ The T/R mice were routinely inoculated with $10^{5}$ AFB in both hind footpads and scored positive (confirming the presence of viable AFB) if $5 \times 10^{5}$ or more AFB were recovered by 12 months. When yields of AFB from biopsy specimens were low or even uncountable, inocula necessarily included fewer than $10^{4}$ or $10^{5} \mathrm{AFB}$. In such experiments a fivefold increase in yield or a yield of $5 \times 10^{4}$ (lower limit of assessment) resulting from an uncountable inoculum was scored positive.

Footpad tests were used to determine the sensitivity of $M$ leprae to rifampicin and to determine the viability of $M$ leprae.

Sensitivity to rifampicin-Ten strains of $M$ leprae, four from untreated patients and six from patients with sulphone-resistant lepromatous leprosy, were tested. Four groups of six normal mice were infected with each strain; three groups were fed with rifampicin incorporated in the diet at concentrations of $0.01 \%, 0.005 \%$, and $0.0025 \%$, and the fourth was left untreated. The minimum effective dose of rifampicin was calculated on a body-weight basis from the lowest concentration of drug in the diet that completely suppressed the growth of AFB.

Viability of $M$ leprae-Tissue specimens were obtained by biopsy from patients before and during treatment; they were homogenised 
and bacillary suspensions were prepared ${ }^{5}$ for footpad inoculations of normal or $T / R$ mice, or both.

\section{CLINICAL STUDIES}

We performed four carefully designed clinical trials.

\section{Pilot studies of rifampicin}

Rifampicin $600 \mathrm{mg} /$ day was given to six active untreated patients with lepromatous leprosy, and the response assessed clinically, bacteriologically, and histologically. ${ }^{1}$ The bacteriological assessment consisted in calculating the bacterial index (BI) and morphological index (MI) from skin smears. This original pilot trial was extended and additional patients were studied, two of whom volunteered to undergo multiple serial skin biopsies, so that the rate of kill of $M$ leprae could be assessed not only indirectly by the MI, but also directly by mouse footpad inoculation.

A total of 25 patients were treated, including two who received intermittent rifampicin, $900 \mathrm{mg} /$ week for six to eight weeks. Eighteen patients were suffering from lepromatous leprosy, five with borderline lepromatous leprosy, one with borderline leprosy, and one with borderline tuberculoid leprosy. ${ }^{7}$

\section{Controlled trials}

Two small, limited, but detailed controlled trials were undertaken on volunteers with untreated active lepromatous leprosy, who were allocated to treatment groups by random distribution.

In the first trial patients were treated for four and a half months with either rifampicin $600 \mathrm{mg} /$ day (three patients) or oral dapsone $100 \mathrm{mg} /$ day (four patients). Independent clinical and histological assessments were performed at the start and end of the trial. Skin smears were examined every two weeks for the first six weeks, and thereafter every six weeks, and skin lesions were biopsied at the start of treatment and after three and six weeks to follow the rate of kill of $M$ leprae as assessed by viability studies in mice.

In the second trial rifampicin $600 \mathrm{mg} /$ day combined with dapsone $100 \mathrm{mg} /$ day (five patients) was compared with dapsone $100 \mathrm{mg} /$ day alone (six patients) over six months. Clinical, histological (skin), and smear assessments were performed at similar intervals to those in the first trial. Fresh and fixed tissue samples were obtained by biopsy at the start and after three and six months' treatment from extensor skin, striated muscle (triceps or quadriceps femoris), nerve (usually the superficial radial), and, in men, dartos (for smooth muscle and fine nerves). The presence of persisting viable $M$ leprae $^{8}$ was assessed in the fresh tissue biopsies by mouse footpad inoculation and in the fixed tissues by histological examination for solid-staining (presumed viable) AFB.

\section{Long-term trial in patients with sulphone-resistant leprosy}

From August 1968 to May 197467 patients were admitted to this open-ended trial; so far they have been followed up for three to eight and a half years. Sixty-five had leprosy that had proved resistant to dapsone, ${ }^{9}$ including five who were also resistant to thiambutosine; two additional patients suffered from sulphone allergy and had developed thiambutosine resistance.

TABLE I-First controlled trial: infectivity (viability) in mice of $M$ leprae from the skin of patients with lepromatous leprosy treated with dapsone $100 \mathrm{mg} /$ day or rifampicin $600 \mathrm{mg} /$ day for six months. Figures in parentheses show actual numbers of positive footpads out of numbers tested

\begin{tabular}{|c|c|c|c|c|c|c|}
\hline & \multicolumn{6}{|c|}{$\%$ Of positive footpads after weeks of treatment: } \\
\hline & \multicolumn{2}{|c|}{0} & \multicolumn{2}{|c|}{3} & \multicolumn{2}{|c|}{6} \\
\hline & $\begin{array}{c}\text { Normal } \\
\text { mice }\end{array}$ & $\begin{array}{l}T / R \\
\text { mice }\end{array}$ & $\begin{array}{c}\text { Normal } \\
\text { mice }\end{array}$ & $\begin{array}{l}T / R \\
\text { mice }\end{array}$ & $\begin{array}{c}\text { Normal } \\
\text { mice }\end{array}$ & $\begin{array}{l}T / R \\
\text { mice }\end{array}$ \\
\hline Dapsone $(n=4)$ & 88 & 92 & 94 & 90 & 81 & 98 \\
\hline Rifampicin $(n=3)$ & 85 & 84 & $8(3 / 36)$ & $3(1 / 34)$ & $3(1 / 36)$ & $3(1 / 30)$ \\
\hline
\end{tabular}

$\mathrm{n}=$ Number of patients.

$\mathbf{n}=$ Number of patients.
$\mathbf{T} / \mathbf{R}=$ Thymectomised-irradiated.
TABLE II-Second controlled trial: infectivity (viability) in mice of $M$ leprae from skin, nerve, striated muscle, and dartos of patients with lepromatous leprosy treated with dapsone $100 \mathrm{mg} /$ day either alone (six patients) or combined with rifampicin $600 \mathrm{mg} /$ day (five patients)

\begin{tabular}{|c|c|c|c|c|c|c|c|}
\hline \multirow{3}{*}{ Treatment } & \multicolumn{5}{|c|}{ Proportion of: } & \multirow{3}{*}{$\begin{array}{c}\text { Sites } \\
\text { yielding } \\
\text { positive } \\
\text { footpads }\end{array}$} & \multirow{3}{*}{$\begin{array}{l}\text { Patients } \\
\text { yielding } \\
\text { positive } \\
\text { footpads }\end{array}$} \\
\hline & \multicolumn{5}{|c|}{$\begin{array}{l}\text { Footpads showing multiplication } \\
\text { (at each biopsy site) }\end{array}$} & & \\
\hline & Skin & Nerve & Muscle & Dartos & Tutal & & \\
\hline \multicolumn{8}{|c|}{ After three months' treatment } \\
\hline $\begin{array}{l}\text { Dapsone } \\
\text { Dapsone and } \\
\text { rifampicin }\end{array}$ & $\begin{array}{r}22 / 54 \\
1 / 52\end{array}$ & $\begin{array}{r}15 / 50 \\
2 / 50\end{array}$ & $\begin{array}{l}9 / 54 \\
5 / 48\end{array}$ & $\begin{array}{l}5 / 44 \\
4 / 38\end{array}$ & $\begin{array}{l}51 / 202 \\
12 / 188\end{array}$ & $\begin{array}{r}11 / 23 \\
5 / 19\end{array}$ & $\begin{array}{l}5 / 6 \\
3 / 5\end{array}$ \\
\hline \multicolumn{8}{|c|}{ After six months' treatment } \\
\hline $\begin{array}{l}\text { Dapsone } \\
\text { Dapsone and } \\
\text { rifampicin }\end{array}$ & $\begin{array}{l}1 / 53 \\
1 / 40\end{array}$ & $\begin{array}{l}8 / 52 \\
0 / 42\end{array}$ & $\begin{array}{l}4 / 48 \\
1 / 30\end{array}$ & $\begin{array}{l}6 / 46 \\
0 / 40\end{array}$ & $\begin{array}{r}19 / 199 \\
2 / 152\end{array}$ & $\begin{array}{l}7 / 23 \\
2 / 18\end{array}$ & $\begin{array}{l}3 / 6 \\
1 / 5\end{array}$ \\
\hline
\end{tabular}

The first four patients who were admitted, and all those who were resistant to thiambutosine, were treated with rifampicin $600 \mathrm{mg} / \mathrm{day}$. The remainder received combined treatment with rifampicin, usually $600 \mathrm{mg} /$ day, though seven received intermittent (weekly) rifampicin, and thiambutosine $1 \mathrm{~g}$ twice daily by mouth or $1 \mathrm{~g}$ weekly by injection.

Regular independent clinical, histological, and bacteriological assessments were performed; episodes of erythema nodosum leprosum (ENL) were noted; and sera from patients on intermittent treatmen were monitored for rifampicin-dependent antibodies. ${ }^{10}$ Thirty-three patients were specially studied for the presence of persisting, viable $M$ leprae in biopsy specimens taken from skin, striated muscle, nerve, and, in men, dartos after six months and one, two, two and a half, ${ }^{11}$ or five years of continuous treatment.

\section{Results}

\section{MINIMUM EFFECTIVE DOSE OF RIFAMPICIN}

In mice all 10 strains of $M$ leprae, whether sensitive or resistant to dapsone, were inhibited by doses of rifampicin of $20 \mathrm{mg} / \mathrm{kg}$ body weight/day and $10 \mathrm{mg} / \mathrm{kg} /$ day; three strains were also inhibited by $5 \mathrm{mg} / \mathrm{kg} /$ day. The minimum effective dose of rifampicin in the mouse is therefore about $8 \mathrm{mg} / \mathrm{kg} /$ day.

\section{PILOT TRIAL}

All patients showed a rapid clinical response to rifampicin. The $M I$ from skin smears fell appreciably after two weeks' treatment in almost all patients, and in all it approached zero after only four to six weeks.

\section{CONTROLLED CLINICAL TRIALS}

The first trial confirmed that the initial clinical response and rate of fall in the smear MI occurred much more rapidly with rifampicin than with dapsone. Blockage of the nose was relieved, superficial scabbing and ulceration of lepromatous papules healed, and lesions became less erythematous and papules less tense and fleshy within 10 to 21 days. The comparable response on dapsone took six to 12 weeks. Mouse footpad testing (table I) showed that after only three weeks very few leprosy bacilli from rifampicin-treated patients could multiply, whereas no loss of viability could be detected at six weeks in patients on dapsone.

Multiple-site biopsies taken at three months in the second trial showed significant loss of bacterial viability in both treatment groups, although the loss was much greater on combined treatment than on dapsone alone. At six months 19 out of 199 footpads inoculated with $M$ leprae prepared from the tissues of dapsone-treated patients showed bacterial multiplication compared with only two out of 152 footpads from the combined treatment group (table II). There was no evidence that after this length of treatment any one of the four tissue sites favoured the persistence of $M$ leprae.

Although we got the impression that ENL developed on average earlier in patients treated with rifampicin than in those receiving dapsone alone, we studied too few patients to attain significant results. The overall severity of ENL experienced by individual patients seemed to be unrelated to the treatment group to which they belonged. There was no evidence of a sudden, severe onset of ENL, comparable to a 
Jarisch-Herxheimer reaction in patients with syphilis treated with penicillin.

\section{LONG-TERM TRIAL}

All the patients who were resistant to dapsone showed the same rapid initial clinical improvement and fall in the MI on rifampicin as the untreated patients. After the first three or four months of treatment, however, the subsequent rate of progress was much the same as that under treatment with clofazimine (Lamprene, B 663), including the rate of removal of dead leprosy bacilli as assessed by the BI of skin smears. ${ }^{11} 12$

Persisting viable $M$ leprae were detected in 26 of the 33 patients specially studied by biopsies of multiple tissue sites (table III); all four sites were implicated. The proportion of positive sites was no less after two years than after six months or one year of treatment. Moreover, even after five years of rifampicin treatment seven out of 12 patients had at least one site (table IV) that yielded viable $M$ leprae; they included seven of the eight patients who had biopsy specimens taken from at least three sites.

Three strains of $M$ leprae isolated from patients treated for six months were shown to be fully sensitive to rifampicin.

TABLE III-Long-term trial: infectivity (viability) in mice of $M$ leprae obtained from four tissue sites in 33 patients with lepromatous leprosy resistant to dapsone who were treated with rifampicin for six months to five years

\begin{tabular}{|c|c|c|c|c|c|}
\hline \multirow{2}{*}{$\begin{array}{c}\text { Duration of } \\
\text { treatment } \\
\text { (years) }\end{array}$} & \multicolumn{4}{|c|}{$\begin{array}{l}\text { Proportion of biopsies yielding } \\
\text { positive footpads from tissue sites: }\end{array}$} & \multirow{2}{*}{$\begin{array}{l}\text { Proportion of patients } \\
\text { yielding positive } \\
\text { footpads from at } \\
\text { least one biopsy site }\end{array}$} \\
\hline & Skin & Nerve & Muscle & Dartos & \\
\hline $\begin{array}{l}6 \text { months } \\
1 \\
2 \\
2 ! \\
5\end{array}$ & $\begin{array}{l}1 / 6 \\
3 / 9 \\
3 / 11 \\
0 / 1 \\
6 / 12\end{array}$ & $\begin{array}{l}1 / 6 \\
2 / 10 \\
4 / 9 \\
4 / 6\end{array}$ & $\begin{array}{l}1 / 5 \\
4 / 9 \\
4 / 10 \\
0 / 1 \\
3 / 8\end{array}$ & $\begin{array}{l}2 / 2 \\
2 / 8 \\
5 / 6\end{array}$ & $\begin{array}{l}4 / 6 \\
8 / 10 \\
9 / 11 \\
0 / 1 \\
7 / 12^{*}\end{array}$ \\
\hline
\end{tabular}

*Seven of these patients were also investigated at two years (6) or two and a half years (1).

TABLE IV-Long-term trial: proportion of mouse footpads showing multiplication of $M$ leprae obtained from four tissue sites in 12 patients with lepromatous leprosy resistant to dapsone who were treated with rifampicin for five years

\begin{tabular}{|c|c|c|c|c|}
\hline & \multicolumn{4}{|c|}{ Biopsy sites } \\
\hline & Skin & Nerve & Muscle & Dartos \\
\hline $\begin{array}{l}\text { Proportion of positive footpads } \\
\text { (all patients) } \\
\text { Proportion of positive footpads in eight } \\
\text { patients who had three or four sites } \\
\text { biopsied .. }\end{array}$ & $\begin{array}{r}15 / 114 \\
15 / 74\end{array}$ & $5 / 46$ & $\begin{array}{l}13 / 72 \\
13 / 72\end{array}$ & $\begin{array}{l}12 / 84 \\
12 / 56\end{array}$ \\
\hline
\end{tabular}

\section{RIFAMPICIN TOXICITY}

One patient developed jaundice associated with occult cirrhosis while taking rifampicin, and treatment was changed to clofazimine. The one patient who received $600 \mathrm{mg}$ of rifampicin weekly complained after three years of treatment of fever and abdominal symptoms that developed about two hours after each dose. No rifampicin-dependent antibodies could be detected, and her symptoms were completely relieved when she changed to daily rifampicin. Rifampicin-dependent antibodies were detected at four, but not at five years, in one of two patients receiving rifampicin $900 \mathrm{mg} /$ week; he remained symptom free and his dose was left unchanged.

\section{Discussion}

In many ways dapsone is an ideal drug for leprosy control programmes, being both very cheap and relatively non-toxic. Nevertheless, we have identified two major problems associated with its use-namely, the development of dapsone resistance in lepromatous and borderline lepromatous leprosy ${ }^{913}$ and the persistence of a few drug isensitive leprosy bacilli ("persisters") despite 10 to 12 years' supervised continuous treatment. ${ }^{8} \mathrm{By}$ analogy with the chemotherapy of tuberculosis, ${ }^{14}$ alternative, preferably bactericidal, drugs are required for an intensive initial phase of combined treatment. ${ }^{15}$ This would be used principally to prevent the later emergence of dapsone resistance but also in an attempt to hasten the elimination of persisters and thereby to shorten the often lifelong period of treatment required in lepromatous leprosy.

Rifampicin has proved promising since its introduction. Clinical improvement can be detected within two weeks, although in the long term there is no evidence that rifampicin speeds the removal of dead leprosy bacilli..112 The drug is more rapidly bactericidal than any established anti-leprosy drug; this has been shown both indirectly by the rate of fall of the MI and directly by mouse footpad inoculation of suspensions obtained from either serial skin biopsies" ${ }^{34}$ or serial "nose-blows" ( $R$ J W Rees and A C McDougall, unpublished observations, 1973). Patients with lepromatous leprosy ceased to present a significant public health risk within a few days of starting rifampicin, and provided that the precautions recommended from experience in the treatment of tuberculosis ${ }^{16} 17$ were observed, the toxic effects of rifampicin were negligible. ENL was no more severe than with dapsone.

Our pilot studies ${ }^{1}$ and the extensive studies of Shepard et al, ${ }^{34}$ also suggested that rifampicin rapidly reduced persisters to undetectable levels. But, by using a more sensitive technique, giving inocula of up to $10^{5}$ bacteria to $T / R$ mice, we have been able to detect persisters five years after the start of treatment with rifampicin alone or combined with the bacteriostatic drug thiambutosine. ${ }^{11}$ It therefore seems unlikely that rifampicin by itself could significantly shorten the total length of treatment in lepromatous leprosy. Furthermore, the first case of leprosy resistant to rifampicin has already been reported $^{18}$ in a patient receiving treatment with rifampicin.

Combined treatment needs further investigation. In full dosage dapsone is slowly bactericidal for $M$ leprae. ${ }^{19}$ In our studies persisters were barely detectable in dapsone-sensitive patients treated for six months with rifampicin $600 \mathrm{mg} /$ day plus dapsone $100 \mathrm{mg} /$ day and were significantly less common than in patients treated with dapsone alone. It is also reasonable to assume that an initial course of combined treatment would largely prevent the later emergence of dapsone resistance (provided that dapsone continued to be taken regularly), although it may require 30 years to prove this. The other bactericidal anti-leprosy drugs, which can be combined with rifampicin in treating patients resistant to dapsone, are clofazimine and ethionamide or prothionamide. ${ }^{20}$

It is possible, again by analogy with tuberculosis, that an initial intensive phase of treatment with three or four drugs might be even more effective than dual treatment. Freerksen ${ }^{21}$ has advocated the widespread and prolonged use of combinations of dapsone, rifampicin, prothionamide, and isoniazid (although the latter drug has little effect on leprosy bacilli), but his trials did not include adequate bacteriological investigations. He therefore, assessed his regimen by stopping all treatment after various periods and monitoring the subsequent relapse rate $^{22}$-an effective "test of cure," although demanding for both the doctor and his patients.

Such a test of cure needs to be applied very cautiously, for there is no anti-leprosy drug comparable with pyrazinamide, which can act on semi-dormant tubercle bacilli. ${ }^{23}$ Moreover, patients with lepromatous leprosy are incapable of producing effective cell-mediated immunity against $M$ leprae, even after many years of treatment. Therefore multiple drug combinations may be incapable of eliminating all persisting $M$ leprae. Should this prove to be so then the final cure of lepromatous leprosy, if it is to be achieved in years rather than decades, may well depend not on chemotherapy alone, but on a combination of chemotherapy and immunotherapy.

We thank Dr M K Bhojwani for clinical assessments; Dr D S Ridley (Hospital for Tropical Diseases, London) for histological assessments; Encik Mohd Bakri for bacteriological assessments; Dr A C 
McDougall (The Slade Hospital, Oxford) for histological examination of tissues for persisting $M$ leprae; and Dr Sheila Worlledge (Royal Postgraduate Hospital, London) for serological examination for rifampicin-dependent antibodies. We also thank Lepetit Spa, Milan, for supplying rifampicin. The Leprosy Research Unit, National Leprosy Control Centre, Sungei Buloh, is sponsored jointly by the Malaysian Ministry of Health and the (British) Medical Research Council.

\section{References}

${ }^{1}$ Rees, R J W, Pearson, J M H, and Waters, M F R, British Medical fournal, 1970, 1, 89.

2 Leiker, D L, and Kamp, H, Leprosy Review, 1970, 41, 25.

${ }^{3}$ Shepard, C C, Levy, L, and Fasal, P, American fournal of Tropical Medicine and Hygiene, 1972, 21, 446.

4 Shepard, C C, Levy, L, and Fasal, P, American fournal of Tropical Medicine and Hygiene, 1974, 23, 1120.

${ }^{5}$ Rees, R J W, British fournal of Experimental Pathology, 1964, 45, 207.

${ }^{6}$ Rees, R J W, Nature, 1966, 211, 657.
${ }^{7}$ Ridley, D S, and Jopling, W H, International fournal of Leprosy, 1966, 34, 255.

8 Waters, M F R, et al, Leprosy Review, 1974, 45, 288.

${ }^{9}$ Pearson, J M H, Rees, R J W, and Waters, M F R, Lancet, 1975, 2, 69.

10 Poole, G, Stradling, P, and Worlledge, S, British Medical Fournal, 1971, 3, 343.

${ }^{11}$ Rees, R J W, et al, International fournal of Leprosy, 1976, 44, 159.

12 Waters, M F R, Leprosy Review, 1977, 48, 95.

${ }_{13}$ Pettit, J H S, and Rees, R J W, Lancet, 1964, 2, 673.

14 Fox, W, and Mitchison, D A, American Review of Respiratory Disease, $1975,111,329,845$.

15 World Health Organisation Expert Committee on Leprosy, Fifth Report, Technical Report Series No 607. Geneva, WHO, 1977.

16 Aquinas, M, et al, British Medical fournal, 1972, 1, 765.

17 Girling, D J, fournal of Antimicrobial Chemotherapy, 1977, 3, 115.

18 Jacobson, R R, and Hastings, R C, Lancet, 1976, 2, 1304.

19 Levy, L, Antimicrobial Agents and Chemotherapy, 1976, 9, 614.

${ }^{20}$ Committee on Experimental Chemotherapy, Bulletin of the World Health Organisation, 1976, 53, 425.

${ }^{21}$ Freerksen, E, Leprosy Review, 1975, 46, suppl, p 25.

${ }_{22}^{2}$ Depasquale, G, Leprosy Review, 1975, 46, suppl, p 215.

${ }^{23}$ Ellard, G A, Leprosy Review, 1975, 46, suppl, p 41.

\title{
Familial thrombosis : inherited deficiency of antithrombin III
}

\author{
M MACKIE, B BENNETT, D OGSTON, A S DOUGLAS
}

British Medical fournal, 1978, 1, 136-138

\section{Summary and conclusions}

Several members of a family living on the west coast of Scotland and on one of the islands off the coast had serious thrombotic disease. The plasma antithrombin III (ATII) concentrations were measured by both functional and immunological assay in all available members of the family. Concentrations were $25 \%$ to $66 \%$ of normal in 12 people, including all seven with thrombotic disease. The inheritance pattern was characteristic of an autosomal dominant disorder. Thrombotic disease generally affected the leg, mesenteric, and axillary veins, although one man who had died before the study began had had severe arterial atheroma. In women the first thrombotic symptoms usually occurred during pregnancy.

None of these patients have developed thrombotic symptoms until they were at least 18 , so four younger members of the family who have ATIII deficiency but no thrombotic disease may eventually develop symptoms.

\section{Introduction}

Thrombin is a proteolytic enzyme that cleaves fibrinopeptides $A$ and $B$ from the $\alpha$ - and $\beta$-chains of fibrinogen. The resulting soluble fibrin monomers then polymerise to form

\footnotetext{
University Departments of Medicine and Physiology, University of Aberdeen, Aberdeen AB9 2ZD

M MACKIE, BMEDBIOL, MRCP, lecturer in medicine

B BENNETT, MD, MRCP, Wellcome senior research fellow and senior lecturer in medicine

D OGSTON, MD, FRCP, regius professor in physiology

A S DOUGLAS, MD, FRCP, regius professor of medicine
}

insoluble fibrin, which forms the matrix of blood clots. While thrombin is inhibited by $\alpha_{2}$-macroglobulin and $\alpha_{1}$-antitrypsin, ${ }^{12}$ the main physiological inhibitor of thrombin is antithrombin III (ATIII). ${ }^{3}$ The physiological importance of ATIII is emphasised by the fact that it inhibits other activated coagulation factors, including factors IXa, Xa, XIa, and XIIa. ${ }^{4-7}$ These inhibitory actions of ATIII are accelerated in the presence of low heparin concentrations and ATIII is probably identical with the agent formerly known as plasma heparin cofactor. ${ }^{8-10}$

A predisposition to venous thrombosis, such as is acquired during oestrogen treatment and surgery, has been associated with reduced ATIII concentrations. ${ }^{811-13} \mathrm{~A}$ clearer association of venous thrombosis with reduced concentrations of this coagulation inhibitor occurs in the rare hereditary deficiency of ATIII. ${ }^{14}$ We describe here a large family in which major thromboembolic disease was associated with ATIII deficiency. To our knowledge this represents the first such family studied in the British Isles.

\section{Patients and methods}

A family of 64 members, most of whom lived on the west coast of Scotland or one of the islands off the coast, was studied. Plasma ATIII concentrations were measured by both functional and immunological methods; each value shown here represents the mean of two or more separate assays. The results of all assays of ATIII, $\alpha_{2}$-macroglobulin, and $\alpha_{1}$-antitrypsin are expressed as a percentage of a standard plasma pool.

Test plasma-Nine volumes of whole blood were added to one volume of filtered $3.8 \%$ sodium citrate in polystyrene tubes. Plasma was separated by centrifugation for 15 minutes at $2500 \mathrm{rpm}$ and was stored in plastic containers at $-20^{\circ} \mathrm{C}$ until assayed.

Standard plasma pool-Fresh citrated plasma was collected as above from 20 healthy male medical students. The plasmas were pooled, mixed, and frozen in aliquots at $-20^{\circ} \mathrm{C}$.

Normal controls-These were medical and laboratory staff and students free from intercurrent and chronic disease, none of whom had ever sustained an episode of thromboembolism or superficial phlebitis.

Functional ATIII assay-The progressive antithrombin assay, after heat defibrination of plasma, was used. ${ }^{15}$ 